\title{
CENTER AND PERIPHERIES IN EUROPEAN SOCIETIES
}

\section{CENTRO E PERIFERIAS NAS SOCIEDADES EUROPEIAS}

\author{
Mariateresa Gammone \\ Dipartimento MESVA, Università dell'Aquila, Piazzale S. Tommasi n.1, 67100 L'Aquila, Italia. Email: \\ mariateresa.gammone@univaq.it
}

\begin{abstract}
The aim of this study is to examine the relationship between center and periphery, within a sociological tradition that includes authors such as Max Weber and Stein Rokkan. The value of Europe is best perceived along its borders. The light shines strongest in the point of its source, but it is more appreciated to the point of its limit, where darkness and brightness compete for space - and even for life. Southern and eastern European societies are crucial to understand the origins and future of all of Europe. This article aims to explore the reasons for the EU's eminence, which can be maximized rather than minimized.
\end{abstract}

Keywords: sociology, Europe, south, frontiers.

Resumo: Este estudo avalia a relação entre centro e periferia, recorrendo a uma tradição sociológica que inclui autores como Max Weber e Stein Rokkan. O valor da Europa é melhor percebido ao longo de suas fronteiras. A luz brilha mais forte no ponto de sua fonte, mas é mais apreciada no ponto de seu limite, onde a escuridão e a luminosidade competem pelo espaço - e também pela vida. As sociedades do sul e do leste da Europa são fundamentais para entender as origens e o futuro de toda a Europa. Este artigo tem por objectivo discutir as razões da eminência europeia, que podem ser maximizadas e não minimizadas.

Palavras-chave: sociologia, Europa, sul, fronteiras.

\section{Peripheries, borders, frontiers and PIGS}

I present here some results of a project, launched in 2008 with the support of the European Union, which started together with the German universities of Heidelberg and Ludwigsburg and various universities in Turkey. The project ("EU and Turkey: Connecting Identities, Bridging Cultures") is still underway through the collaboration of my university. At the various stages of the project, we have published many books and articles on the different themes (Gammone, 2015; Gammone \& Sidoti, 2012).

Regarding southern European societies, several kinds of definitions are often at play. Not only have specific definitions been discussed; the logical nature of, and historical demands on, definitions have also been discussed. Polysemy, moral 
ambiguity and referential uncertainty concern the expressions "Southern Europe" and "Balkan Europe".

In our pages we study the importance of the idea of frontier in this thematic area. We will emphasize the link between the idea of a border and the idea of a public community, which is also classically defined by the idea of its frontiers. A community must have definitions of what is common and what is different, alien and perhaps enemy. Spatial and ideal definitions of a frontier give mechanisms of inclusion and exclusion.

As F.J. Turner emphasized the importance of the frontier in shaping American character, we can also see the importance of the frontier in shaping the European mindset. In the past, the European frontiers have seen war and carnage. To avoid incorrect polysemous interpretations, I will focus on boundaries.

According to Braudel, European identity was described through visions concerning south and north. Moreover, the values of Europe are best perceived along its borders. The light shines strongest in the point of its source, but it is more appreciated to the point of its limit, where darkness and brightness compete for space and even for life. Southern European societies may be seen as a problem, yet they are the frontiers: crucial to understanding the origins and future of Europe as a whole. Sometimes, an institutional breakdown begins at the peripheries and then sweeps the center away. Conversely, good borders allow good life even in the center (Shils, 1975).

In 21st century Europe, a new cultural divide is suggested to have arisen, challenging the old primary political cleavage over economic conflicts and confronting countries such as Denmark, Norway and Germany with countries such as Portugal, Italy, Greece and Spain. In 2008 and 2009, financial markets had responded with anxiety to the debt crisis that had escalated in Southern European countries, as the EU and IMF called for the enactment of austerity measures and provided financial bailouts to preserve the stability of the euro. The Financial Times ran a piece, headlined Pigs in muck, 15 September 2008. The article was accused of racism and caused trouble. Portugal's Economy Minister Manuel Pinho said "I am deeply offended that anyone would label my country with this term". PIGS has been used as an abbreviation at least since 1999, referring to the Southern European countries of Portugal, Italy, Greece, and Spain. The term looked an apt description for countries that allowed citizens' benefits to go well beyond the means of their governments. The proceedings dragged on for years. The pig is associated in colloquial English not only with dirt but also with supposed inhumane deficiencies in humans. In the language, nationalism and even patriotism are sometime the last refuge of a scoundrel, a chauvinist, a racist, a suprematist, a lunatic (an insane person). The acronym was unfair and 
incorrect; for instance, Spain had been running budget surpluses in the years leading up to the crisis. Greece escaped the grip of catastrophe. In 2017, Italy's current account surplus of euros $47 \mathrm{bn}$ was the third-largest in the EU after those of Germany and the Netherlands. The strength of the Portuguese recovery is astonishing: this experience is almost unique within the euro area.

All states are today embedded in the same global system and subjected to the same issues that are transforming and deforming national societies everywhere. It is not by chance that some speak of "the end of societies" (Touraine, 2013). In the West, global financial capitalism has broken off many links with industrial and national economies, which are steadily losing their institutional and even cultural hegemony (Gammone, 2017).

A major political event of our era is the waning of the nation state: its inability to withstand global 21st-century tendencies and its shattering loss of power over many challenging emergencies. In the West, political authority is in decline and global political authority is emerging slowly, occasionally and sometimes abruptly (Sartori, 2011). Hard-line nationalism seems to be a reliable remedy, a tested answer, a certain solution in an uncertain world.

What continue to exist are the reasons for EU strength and eminence, which can be maximized rather than minimized (Aron, 1977). It is in the advantage of the EU to ensure that the frontiers are not a barrier to economic, educational, and intellectual interchange. Such a warning was declared in Regulation No. 1931/2006 of the European Parliament and of the Council laying down indications on regional trade at the frontiers.

In the nineteenth and twentieth century the European states had to deal with many peripheries, some inside the big cities and in the countryside; others at the geographical peripheries of the nation. All these peripheries were also frontiers (physical and ideal, material and immaterial); they constituted a challenge for every European state: a reflection on the borders is necessarily a reflection on the challenges and on the need to maintain a national (internal and external) coherence. After the Second World War, the creation of the EU was made precisely to avoid the errors and horrors of the past.

To some observers, the EU's borders have been politically and culturally overextended; to them, Eastern Europe belongs not with the West, but with pre-modern mentality. The cases of Hungary and Poland would speak in favor of that interpretation: their institutional culture and political mentality would be distant from the western world. Critics say: unlike Western Europe, eastern European states have not moved from a materialist to a post-materialist culture; they do not have a cosmopolitan outlook, but a nationalistic one; they disregard the western 
systems of checks and balances and do not have those strong democratic traditions which have long safeguarded western democracies.

The Visegrád Group is a political alliance of the (momentary) leaders in four European nations: the Czech Republic, Hungary, Poland and Slovakia, which view Brussels with contempt on every front. Despite their references to the medieval Congress of Visegrád in 1335 and to (restless and turbulent) membership in the Habsburg Empire, the four countries are characterized by being satellite states of the Soviet Union. During the often chaotic transition to democracy, some oligarchs emerged to take a disproportionate share of the economic gain, spreading corruption, cronyism and distrust. Romania is another case in point. Many aspects of present Eastern Europe can be explained by the five decades of the Iron Curtain that marred the area between 1940 and 1990. In this perspective it is easy to understand why their leaders speak in an illiterate way about "illiberal democracy". The liberal tradition, invented in circa 1215 at Runnymede, has never sunk strong roots in some parts of Europe.

Some problems typical of the Visegrád Group countries also exist in other European states, which are already in the EU (such as Romania and Bulgaria) or have been candidated to join the EU (such as Serbia or Albania or Kosovo). In this perspective, some observers speak of a Balkan Europe: another entity that is supposed to be separate and distinct from predominant Europe that is supposed to be irreproachable, without stain and without sin. The most malevolent critics argue that centuries of Ottoman rule have left their mark on the common attitude towards public power. In comparison to the problems posed by the Mediterranean countries, the problems posed by the Eastern European countries and Balkan European countries, are, in many ways, much more stringent. Some states in those areas are accused of being narco-states and others are accused of racism.

The case of Poland is particularly impressive. It is the country that, through the decades, has benefited the most from the strongest international solidarity and that has had immense, direct and indirect, benefits from Europe; yet it is the country that has expressed the most nationalist government, very quarrelsome not only with Europe but even with Israel. In Poland, nationalistic voting is not driven by economic factors (Poland has one of the fastest growths within the EU), but ideational ones, supported even by those who are satisfied with their lives.

Anti-system feelings are not unique to Eastern Europe, as revealed by the election of Donald Trump in the US. Anti-European feelings are not unique in Poland; Brexit was the biggest political shake-up in democratic Europe since the Second World War. However the weight of a pre-modern mentality is judged to be more substantial within eastern European countries: in the geographical definition there is an indication of a distance from the heart of Europe and of a proximity to Russia. 
Negative perceptions of Eastern Europe pander to those arguing the need to label Russia as something alien to the West and not belonging to EU civilization (while it is very difficult to think that the country of Tolstoy and Dostoyevsky, Cajkovskij and Shostakovich should be thought as alien to Europe).

\section{The state and the sense of the State}

At the dawn of modernity, Machiavelli begins Il Principe by emphasizing the concept of the State: "All States, all powers, that have held and hold rule over men have been and are either republics or principalities" (Bock, Skinner \& Viroli, 2011, p. 18). It is a step backwards from the Aristotelian tripartition of forms of government and it is a thunderclap; the word state gradually prevails in all European languages, progressively imbued with a superior ethical connotation.

The conceptual nucleus was the Greek polis as a collective body: the form in which the city first emerged in the Mediterranean culture area, one thousand year before Christ. In the West, the first idea of a superior ethical connotation was given by Plato (Crito, 53a) in the dialogue taking place in Socrates' prison cell, where he awaited execution. "Is a city pleasing to anyone without its Laws?" (Popper, 1992, p. 392). Many authors have periodically removed the dust of time from this basic idea. In his pivotal Politiks als Beruf, Max Weber points out: "Machiavelli, in a beautiful passage, if I am not mistaken, of the History of Florence, has one of his heroes praise those citizens who deemed the greatness of their native city higher than the salvation of their souls" (Weber, 2002, p. 76) This idea of ethical superiority was for centuries intrinsic to the idea of the State: a parallel concept that some call the sense of the State; a sense of belonging to something which is superior, defined by borders which must be maintained sacred and safe.

The beginning of Renaissance was in Florence, but it is customary to assume that structures and instructions, practice and rhetoric of the modern European state are above all in French and German culture, from Richelieu (the greatest practitioner of the modern state) to Hegel (the greatest theorist of the state). It is not a Mediterranean glory. The first immense praise of the modern state is found in the dedicatory epistle which accompanies the work on the state of Hobbes (De Cive, X, 1), the forefather of Anglo-Saxon political culture: "outside of the state there is passion, war, fear, poverty, ugliness, solitude, barbarism, ignorance, ferociousness; in the state, reason, peace, security, wealth, beauty, society, elegance, science, benevolence" (Moore, 2011, p. 97). The dividing line between the state and its borders, frontiers, peripheries was clearly traced. 
Hobbes distinguishes public ethics and private morality, which for many were the same thing. In Europe the concept of public ethics had its roots in a centuries-old history of administrative structures. This theoretical framework must be filled by empirical references and thick descriptions.

The modern bureaucratic administration develops in Europe during a very long process, which is expressed in figures like Henry VIII and Friedrich Wilhelm I of Prussia (father of Friedrich "the Great"), which then gradually converges into a unitary model (Barker, 1944; Bendix, 1969). In the European Ancien Régime, dynastic absolutism turns into bureaucratic absolutism, functional to an autocratic and militarized model, brought to an extreme level of perfectionism by the Hohenzollerns. Public ethics was typical of a Garrison State (German version) and with characteristics eminently connected to territorial expansion. The Prussian borders were perpetually moving (as in all the European states): national interest was the supreme interest.

Friedrich Wilhelm I of Prussia was known as Soldatenkönig, the "Soldier King". The military obedience to the state has often been criticized and caricatured, precisely because obedience is not always a virtue, as was clear in Nuremberg trials. The idea of public behavior based on principles of "discipline and honor" (as stated in article 54 of the Italian Constitution and as similarly stated in all the European constitutional papers), marks the link with the sense of the nineteenth-century state. An idea of statehood as a common good remains dominant over several centuries. Discharged by nationalism, militarism, colonialism, the worship of the state is part of a peculiar culture of general interest, in "one of the happy seasons of human knowledge" (Giannini, 1986, p. 46).

The connection between public pedagogy and the worship of the State is evident in some specialized profiles. The nineteenth century was a period characterized, throughout Europe, from France to Turkey, by the attempt to establish homogeneous national societies. A fundamental date for a strongly participated social construction of the sense of the State (as a new, extraordinary and mass phenomenon) is indicated in the advent of public schools, in Northern Europe, especially in Denmark, when, in 1721, Henry IV gave life to the rytterskole (which in a few years becomes mandatory as well as public). The fundamental Generallandschulreglement of Frederick the Great of Prussia comes later: it emerged in 1763-5. In France, La Troisième République and public school are intimately connected. The nineteenth-century idea of the sense of the State assumes the tone of an epic in the most solemn German intellectual works, from Hegel to Laband, from O. Hinze to U. von Wilamowitz-Moellendorff.

The Protestant reform marked a difference that establishes a cleavage not only in comparison to Catholics, but to all other forms of religious belief: Orthodox, 
Islamic, Jewish, and so on, in many ways. Among these profiles the sense of the State is particularly relevant. In the Protestant experience the state substitutes the Church as a primary institution, determinant and enveloping in reference to the various spheres of life. A formula has been indicated as summarizing the meaning of the Reformation: "Everyone now has to be a monk for life" (Weber, 1923, p. 318). A methodical and ascetic conduct impregnates civil life and, above all, the relationship with institutions: the sense of the State is the sense of an inner obligation. In a theoretical perspective, good public service in the state has been experienced by many as a "civil religion" (Bellah \& Tipton, 2007).

The state is the institution that penetrated into the consciousness of many European countries, in a manner that is greatly underlined by both Protestants and Catholics, both right and left. When Gramsci formulated the concept of "passive revolution" for the Italian Risorgimento, he was thinking to a comparison with Protestantism. Without understanding this mass penetration in soul and mind, it would be impossible to fully understand many classical authors, from Hegel's political theology to Weber's bureaucratic typology: both, from different points of view, agree on considering the state as the supreme moment of a progressive historical rationality.

This idea of the state was not typical only of philosophers and professors; it imbues all German-speaking culture, in a pervasive and omnipresent way, starting with the popular classes. It is not an exclusively German affair, so much so that it takes place equally, from Holland to Scandinavia, to Denmark (sometimes those countries indicated to the German-speaking states important choices of public policy, as in the case of education). In France, through different paths (but homogeneous in the result), the lay idea of the République performs the same function. The history of administrative law in France obviously sinks into the history of the Ancien Régime, as the history of Austro-Hungarian good governance sinks into enlightened absolutism. But the different national ways (different in time, motivations and structuring) do not prevent us from seeing the primary genetic moment, which constitutes for all an imitative and emulative moment.

When von Moltke, within a few years, first battled the Danish army, then the Austro-Hungarian army, then the French army, he closed the discussion on the field of the different state models. Convergence towards a common model underwent a powerful acceleration after Sedan. There remained little to discuss about the winning model, in the years when the Prussian army had surrounded Paris.

Modern states are born with the great European monarchies of the seventeenth century. But the signification of the state, in the strongest and most 
meaningful gradation of the term, as a feeling of inner obligation and as we understand it in Europe, arises with the Protestant Reformation, understood as a reform of people, literacy, nationalization. Everyone saw the final result, from Sadowa to Sedan, regardless of the initial religious reasons. And everyone tried to swipe that model, adapting it to national characteristics.

The most refractory to a unitary model, in theory, were the British, but they were the first to see the German model as an example, as well as a mortal danger. When they eliminated clientelism, they had the German case clear. While the Germans, for their part, could point out that they had always taken care to distinguish themselves from the English - as, in a strong and clear way, Hegel had done in 1831, in his fundamental Über die englische Reformbill.

The loans between the various national routes were reciprocal; in the end they arrived at a unitary model: in this sense the European state systems are variants of a prototype that in its theoretical essence exists only in an ideal typology.

\section{Good administration, Southern Europe and Eastern Europe}

In Europe the difference between its center and its peripheries does not correspond to state frontier differences (Gammone, 2014). Within individual states, some internal differences are stronger than differences existing among individual states. Typical is the case of Italy, which in the north has some of the richest regions in Europe and in the south has some of the poorest regions in Europe. Similar problems of regional asymmetries exist in all the major European countries. European society is criss-crossed by inter-state fractures that in some cases add up, turning the differences into a chasm: Catholics versus Protestants, State versus Church, north versus south, east versus west, city versus countryside, democracy versus authoritarianism, center versus periphery. The social map of Europe does not correspond therefore to the institutional divisions, but to these complex divergences, which constitute deep lines of separation, often within the borders of the same state. Religion, economics, politics and literacy draw another cartography compared to the official one of Europe. Modern and industrial Europe is constituted independently of the lines drawn by the states.

In the eighteenth century the axis of industrial revolution unfolds from the triangle Manchester, Liverpool, Birmingham, joins with London, excludes Wales, Scotland, Ireland (which were inside the national borders), and instead joins with Paris, it spreads along the Rhine (involving a part of Germany, France and Belgium), arrives in Milan, Genoa, Turin. 
In Europe the fractures triggered by the industrial revolution overlapped with the cleavages previously determined by different characteristics of economics, religion, literacy (Lipset \& Rokkan, 1967). The incorporation of populations within the same pattern of industrialization has found its limits in the Mediterranean and the Balkans, but expanded where it found premises and opportunities, as in Scandinavia and the Baltic. Some fractures have been absorbed, mediated, defused, others persist, others have been a barrier to modernization: fractures have become a chasm, which seems almost insuperable. The theme of legality is one of these complex and obscure ditches: there are boundaries that unite and there are abysmal borders.

In the nineteenth century, during the construction of their state and nation, all the Europeans, including the French and the English, measured themselves against the cumbersome and threatening German example and sought an original creation, adapted to their local circumstances. In many European countries there was a context that was too heterogeneous compared to the German context. In Southern Europe, traditional societies and pre-unification states were very different from each other. The inclination towards the French centralist example (motivated by heterogeneity, not by ethnic homogeneity) was also due to the awareness of the existing distance with respect to the German model.

To understand how the sense of the State represented a form of national recovery, it is sufficient to remember that often there was (in the European literature on the state) the invitation to not do "as the Italians" (Venturi, 1970, p. 35). There have been great celebrations of the common good in Italy (as in the pictorial cycle of Ambrogio Lorenzetti's Buongoverno, the allegory of Good Government), but there have also been great celebrations of individualism (brought to the fore by an illustrious historiography, Burckhardt in the first place).

The Italian way is individualistic, not opposed to good government. Indeed, it is difficult to find someone who is opposed to honest governance. In Southern Europe, the problem was really constituted by the historical lack of good governance (rectius, a governance as good as the enlightened governors of modern Europe were). Ortega's Espãna Invertebrada developed the theme that in Spain exaggerated individualism had become anarchy. Ortega argued that Spain was dismayed by leaders who had no talent. Their existential inadequacies, Ortega emphasized, were transferred to the institutions these mediocre people headed. Thus, his "invertebration" refers to leaders who are not qualified to lead and who refuse to take advice from those who are qualified. It is a common mistake, to confuse a state with its ruling class, people with oligarchies, a country with its past.

We find the same confused and desperate attempts to vertebrate southern European countries, in the history of eastern European states. Although very 
different, both the Ständestaat idea in Austria and the II Rzeczpospolita Polska are attempts toward a vertebrate modernization. Specifically different, but all equally engaged in dramatic modernization attempts, are Admiral Horthy in Hungary and Corneliu Zelea Codreanu in Romania, Tomáš Masaryk in Czechoslovakia and Józef Klemens Pilsudsk in Poland. The experimental roads were all different, but all aimed at the construction of a vertebrate country. From this point of view, the history of the Mediterranean Europe and the history of Eastern Europe can be seen in the same light, including the reckless oscillation between fascism and communism, between extreme authoritarianism and extreme modernism.

In Europe, the idea of the sense of the State as dedication to good administration (honest, legal, fair, impartial) radiated from the centre to the peripheries: sometimes it dimmed its light in the path from the center to the suburbs. In Mediterranean Europe we encounter state-building problems that also exist in other European countries, from Romania to Poland. Southern European elites supported good governance, but were prevented by hard cleavages.

In some southern and eastern European countries, the sense of the State is often a concept that remains in the field of otherness: distant and alien. Foreign military occupations and internal parasitic dominance characterized a popular way of seeing public power as a stranger or even an enemy, against which it is legitimate not only to disobey but to steal in the first place.

In many southern European countries, the formation of the national state arrived late, so that even the sense of the State arrived late: within the transformation of small kingdoms into European countries. Walking hand in hand with the patriotic ideals and the dream of an independent nation, the sense of the State was popularized slowly, widening with serious difficulties in the social classes that had not passionately traversed the nationalistic season, characterized by very strong spiritual tensions and moral. In the nineteenth century the right conventionally embodied the idea of the state (which in the meantime changed nature, in the transition from the liberal state to the pluralistic and democratic state).

In many southern European countries, as in many countries of Eastern Europe and Balkan Europe, the state was formed in the climate of nineteenth century, under the sign of a paradox: the attempt to follow a local path between the French model étatiste and the English model of the stateless society. The paradox consists in this: the nineteenth-century and twentieth century "late comer" European states were born weak and reacted to their congenital weakness by cultivating disproportionate purposes. 


\section{Southern Europe, Eastern Europe, and the Mediterranean}

Everyone agrees on reading the history of legality within the history of civilization. As the history of legality would be incomprehensible if it were not inserted into the history of civilization, in the same way it would be incomprehensible, if it were not inserted into the history of Europe and the Mediterranean. It is not a matter of reading the history of legality within the history of Europe and the Mediterranean ingeneral, which would be too much: in these pages we are trying to read the history of legality within the history of the sense of the State in Europe and the Mediterranean.

The so called Southern Europe is not only Mediterranean: it is in large part the Balkan and southeastern Europe, extraordinarily different from both the Scandinavian and Hanseatic Europe, and the Rhenish and Carolingian Europe (Le Goff, 2003). Diversity is not only economically evident: it concerns the cultural and behavioral dimensions. There is a Protestant Europe and there is a Catholic Europe; there is an Orthodox Europe and there is an Enlightened Europe (Murteira, 2004).

The differences inside the different geographical areas are more relevant than the differences between the states: often different geographical areas are grouped in states for occasional and fortuitous reasons. When the unification of Italy was completed, the first statistical assessments revealed a southern Italy that in some ways was more similar to Balkan Europe and to Mediterranean Europe (rather than to Northern Italy), from the rates of economic development to the literacy rates, from the distance with respect to feudalism to the distance from secularism.

Feudalism was cut down in southern Italy roughly in the same period in which it was shot down in other areas of Eastern Europe (while in the north of Italy not only had it been knocked down many centuries before, it had been replaced by the brightest phase in history of municipal councils).

In short, between the nineteenth and twentieth century we can see in a filigree the attempts to vertebrate southern European countries: attempts not fully successful, even if the commitment was meritorious. An interpretation underlined the existence in Europe of cleavages connected to the paths of modernization. Historical fractures and political divisions generated intense and lasting conflicts, rooted in the various contexts, which overlap over time around cultural, territorial, economic, and state themes. In this perspective, modernization is an evolutionary process, giving rise to multiple modernities (Eisenstadt, 2007).

In the history of European political and social conflict, there are various institutional discontinuities, which overlap and intertwine, generating strong divisions and differentiations, deep fractures, long-term cleavages, in the perspective of 
the longue durée of Braudel and of the Annales school. These cleavages are typical of many countries. Everywhere, even in Norway (Lipset \& Rokkan, 1967), modernization has created strong resistance, within rural communities and their traditions (Torsvik, 1981). Europe is characterized by historical, institutional, cultural, social fractures, in a tangle of overlaps and interconnections that are still perceived today. These differences draw a different map of Europe, in which institutional divisions are less important than the divisions in terms of economics, literacy, and religion.

The various forms of a paternalistic, protective, interventionist, bureaucratic state, rested on the solid foundations of the absolutist tradition, which dated back to the days of Richelieu and Friedrich Wilhelm. During the nineteenth century, Etat-Providence and Wholfahrtsstaat established themselves with a strong perception of their task in the construction of a "greater public happiness". The term Welfare State is a translation of the German expression Wholfahrtsstaat, a variant of the parallel Polizeistaat, the mighty police-state of the illuminated Prussian absolutism in the eighteenth century. From the administrative patrimonialist structures of the seventeenth century, the various European states merged into a common model, innovatively and ideally addressed to the new challenges of the nineteenth century.

In Europe, the French Revolution of 1789 was above all the victory of the French armies, which everywhere brought the wind of renewal, from the Baltic to the Mediterranean, in institutional and economic contexts that were still feudal. Napoleon's armies favored the collapse of the Ancien Regime, which was in Europe no less radicated and institutionalized than in France. Restoration tried to put back the clocks of history, but in 1848 the "spring of the peoples" revived the dream, in a peremptory manner.

French development has been a model for many European countries, but the French model is not univocal: it goes through convulsive changes, no less than in other European cases. French chronicle is characterized by a series of clashes that were of particular intensity at the beginning of the République and that continue since then:

The Red Terror of 1793-1794 had been imitated by the White Terror of 1815, followed by the terrible repression of the days of June 1848, a prelude to the greatest civil massacre of the nineteenth century in the West: the summary execution of 20,000-30,000 Parisians by the MacMahon's army after the collapse of the Municipality of 1871. (Duverger, 1967, p. 25)

Even after 1871, social conflicts often gave rise to forms of civil war, as in the case of the Dreyfus affair, or in the 1926 crisis, or in the 1929 crisis, or in the years of 
f Petainism: it was a very harsh confrontation, which was repeated with decolonization, when the dynamite attacks did not even save the houses of the philosophers (twice in July 1961 and in January 1962, they ruined the apartment of Jean-Paul Sartre). The image of a chaotic Southern Europe is partial and often pretentious: even pivotal Europe, from France to Germany, have had a very tumultuous political chronicle.

This intense history of that Europe is also a earthquaked institutional history, characterized by clearly visible delays, on the level of principles and civilization. Still in the 1930s, in France of the immortal principles of the Eighty-nine, guillotine was regularly operating and there were public executions by beheading, with the executioner in permanent service. A fanatic eurocentrism should be totally inadequate.

\section{Monopolization of violence, from Gibraltar to the Golden Horn}

Following Ortega y Gasset (2004-20010, IX, p. 269), the state is the superlative of society and it is in essence "an insuperable power facing the individual". The state is a power that is natural, but not self-evident. Its naturalness is predicated upon it being accepted by popular, general, obvious usages. When this naturalness has become daily, the state has become an established means of power, and has come to exert its constraint upon everyone in the form of a binding observance.

Max Weber was the greatest observer of the monopolization of violence carried out by the European states. It is one of their major characteristics, in the general context of the penetration of rationalism in Western society, in many forms, in all spheres of life. The modern state had to expropriate the private practice of violence and allow a rational and legal use of violence. The public monopoly of violence required methodologies applied by specialized personnel, according to criteria of precision, continuity, subordination. The history of the European state coincides to a large extent with the history of its military, police, repressive bodies.

The images of the West would be very provincial if they did not take into consideration the way public order was managed in Europe, before democracy and human rights. In 1845, in England, a very young Engels prophetically saw the terms of the social question in his famous The condition of the working class in England: "What is true of London, is true of Manchester, Birmingham, Leeds, is true of all great towns. Everywhere barbarous indifference, hard egoism on one hand, and nameless misery on the other, everywhere social warfare, every man's house in a state of siege, everywhere reciprocal plundering under the protection of the lawand all so shameless, so openly 
avowed that one shrinks before the consequences of our social state asthey manifest themselves here undisguised, and can only wonder that the whole crazy fabric still hangs together" (Engels, 2009, p. 37).

The point that concerns us is the descriptive part of the police tasks, in a manner consistent with all the subsequent Marxian production, from the Grundrisse to the writings on the Parisian Commune. According to Marx and Engels, the management of public order was everywhere brutal and unscrupulous.

Since Marx and Engels were incurable Communists, therefore suspicious in their descriptions and conclusions, we may find it useful to read what the most unsuspected historians say. It may be helpful to understand the rule of law in "the best" of Europe (not southern and not eastern, not Mediterranean and not Balkan). Great historians say that poor people were faced with perhaps the most brutal penal system in European lands.

Beginning at the end of the seventeenth century, but continuing into the eighteenth, the death sentence was extended to cover all sorts of offences, even those of the most trivial sort. In France nearly every type of theft was punishable by death, regardless of the value of the stolen objects. Vol en grand chemin was punishable by killing the road bandit at the scene of the crime or capture. Vol avec effraction (breaking and entering) was punishable by death by hanging, especially if there had been any violence during the commission of crime. For vol simple (simple theft) the penalty varied according to circumstances; a theft of objects worth 10 livres was punishable by the death sentence in some regions of France. It was in England, however, that the death penalty was extended to cover nearly every sort of crime, particularly any offence associated with the theft of property and personal goods. In 1689 there were about 50 offences punishable by death, and by the end of the eighteenth century had become more than 200 . The English law was revised to include another 33 capital crimes during the reign of George II, and another 63 capital crimes were added to the statute books during the last forty years of the century. The most crucial step was taken in 1723. (Weisser, 1979. p. 138)

The protection of property and large landowners in England had reached terrible levels of severity. In 1758 the Waltham Black Act (passed in 1723 in response to a series of raids by two groups of poachers, known as the Blacks) foresaw the death penalty throughout the realm for poaching and abusive entry into the king's hunting reserves; these extreme measures were after extended to many kinds of criminal offenses! (Weisser, 1979, p. 139).

In Southern Europe the criminal question was a legacy of the Mediterranean question. Following the Weberian terms: in the south, the criminal question is a 
consequence of the incomplete path of monopolization of violence by the state and its structures. In southern Italy, "authorized brigands" were used to support the territorial power of feudal barons, in order to maintain a stable rural context of hunger and misery, brutality and ferocity. The feudal system survived with the fundamental contribution of the brigands, firmly and openly used by the Bourbons against all enemies of the established order: not only the peasants, but the nascent southern bourgeoisie. Many historians incisively narrated the reactionary use of brigands, in political function, in 1799 , in 1805 , in 1815 , in 1820, in 1858 , in 1860 . This is not just an Italian affair. Historians have narrated a likeness in Calabria (with a reasoning which is valid all throughout many southern European areas), for resistance to the French invasion of the region in 1806: "The region gained immense fame and was compared throughout the whole of Europe to the French Vendée" (Caligiuri, 1998, p. 43). In many parts of Europe, from the 14th-century, jacqueries had been performed; in the path of modernity, they transformed into reactionary coalition: a region-wide confrontation of anti-modern majority based in the countryside against a pro-modern minority that had particular strength in the cities.

Considering the specificity, in its European and Mediterranean context, we can realize why in Southern Europe the culture of security has frequently taken roads that are much closer to the Vautrin of Honoré de Balzac than to the different perspective often exemplified in the Metropolitan Police Act of 1829 and in the ideas of Sir Robert Peel (the gentleman policeman). The character of Vautrin was inspired to Balzac by Eugène François Vidocq, a former criminal who later became chief of the Paris police. From the French characters (including Arsène Lupin, the gentleman-cambrioleur, and many others) to the characters of Fritz Lang (in the grim depiction of $M$ - Eine Stadt sucht einen Mörder), police forces did not have an immaculate image in continental Europe. Some pessimistic descriptions have continued until today. This does not mean that Great Britain is a paradise in comparison. Security and peripheries were a huge problem in Britain, with its own dramatic nightmares (Conrad, The Secret Agent; Chesterton, The Man Who Was Thursday: A Nightmare).

History is full of contradictions and surprises. In Southern Europe a careful search of modernity, civilization and elegance existed; in continental Europe, sometimes crooks in power existed; in insular Europe too: for a long time the Irish were perceived as a race apart and often acted as such. In 2018 Ireland celebrates the 20th anniversary of the Good Friday agreements, signed on 10 April 1998. Guests of honor former US President Bill Clinton and former Senator George Mitchell, who had played a crucial role in convincing Catholics and Protestants, 
Republicans and Unionists, to sign the agreement that brought peace back after decades of riots, murders, terrorism. Outside of Europe, even the Chinese, for a long time, were perceived as a race apart and often acted as such; now it is very different. Everywhere, in the world, the old suburbs are upset and the old borders are modified; the European situation suffers a change that is global and general, upsetting and inevitable.

A fundamental profile of Europe is constituted by the juxtaposition of pushes and counter-pushes: not in all countries the contrast between the centralist impulse to the construction of the nation and the reluctance of the peripheries has been resolved. Often the result was a polarization between local centers and specific peripheries. The various forms of corruption, illegality, organized crime in the Italian south should be seen in this light: the consequence of the insufficient development of industrialization, literacy, state structures (including the repressive ones).

The discriminating point in Europe is not Catholicism or Protestantism: the rift is at its origins, in the Mediterranean, where the advance of the Ottoman Empire resumed the previous Islamic wave of the seventh century and commits all southern European countries for almost three hundred years. Muhammad had transformed the Mediterranean into a Muslim lake (Pirenne, 1937); the Ottomans engaged in perpetual war and guerrilla. Braudel (1977) used to say: for centuries the Mediterranean has been a "transport area", an easy and happy means of communication and exchange for the peoples that faced its shores. Then everything changed.

The discriminating point (Lewis, 2001) was not Islam as a religion (because many, beginning with the Jews, saw Islam as a religion protective of minorities, better than Christianity). The discriminating point was the expansionist pressure on the territories. Because of a clash of civilizations (in a not-ethnocentric meaning), in the Mediterranean the modern state has had big difficulty in maintaining the monopoly of violence, because firstly concentrated in a military and geopolitical competition for survival, thus exhausted by pirates and armies on the external front, by brigands and feudal lords on the internal front.

A deadly mixture, from Algiers to Istanbul, has constituted an invisible barrier and a kind of sanitary cord against the full expansion of law and property rights. While on the Atlantic the corsairs are the forerunners of modernity, and then they are eliminated, instead the Mediterranean, in full, sea, coasts, hinterland is infested for centuries by people armed to the teeth, cutthroats and raiders of all realms. Following Pirenne, in the decadence the Mediterranean, the responsibility of the Saracens would be strong: the Tyrrhenian fell into their hands; the Byzantine empire managed to maintain a narrow commercial bridge along the Aegean and the 
Adriatic, but the sword of the barbarian raiders still pierced the Mediterranean for a thousand years. Byzantium and Venice constituted a particular story, which specifies but does not change the general decline; in any case we clearly see the end of the cultural and commercial unit existing in Latin and Hellenistic times.

The sackings and kidnappings (Cervantes spent years in the clutches of the Algerian pirates) hit ships and businesses, the coastal cities of Lazio, Tuscany, and Liguria; they do not spare the French mainland, from Marseilles to Saint-Tropez; the Islamic settlement in Spain becomes a lasting achievement; classical Greece turns into a starting base for raids. The dualism of the Italian case is particularly instructive. The terror that comes from the sea is the catalyst of the ruralization of southern Italy, as indicated by the watchtowers that are still seen, along many parts of the coasts: it was a continuous and fruitful hammering, so much so that the raids went to the Far Oer islands, in the Norwegian Sea, where they incur however in the hard reaction of the Vikings, that overflowed for centuries, as invincible warriors, until are assimilated in various European cultures.

In a prestigious historic perspective, Europe is born from the disintegration of the Hellenistic and Latin unity. The collapse of the Roman Empire and the eruption of Islam would be the preconditions for the birth of modern Europe. Some say that it would be the EU's birth certificate now, with Regesburg instead of Brussels. The Holy Roman Empire of Charlemagne, half Gallic and half Teutonic, would be an anticipation of today's Europe. Charlemagne founded a purely continental power, which became splendid also because it was not afflicted by Mediterranean fears.

Carolingian Europe, especially along the Rhine (Albert, 1991; Febvre, 1935), becomes very different from Mediterranean Europe, as the case of southern Italy shows in full evidence: together with Spain, this was the part of Europe closest to Africa and Islam. With ruralization and pauperization, the splendid city culture of the past ends: the mountains and the countryside become protagonists, in the Malthusian grip of a narrow gap between population and resources, with a cereal cultivation practiced extensively. In the decadence, the archaic pastoral economy dominates: hungry peasants, a lazy and absentee property, a petty bourgeoisie, untrained in commerce and industry. In southern Italy, the feudal lords were very different from the Lombard and Tuscan owners; they wanted to live in the court, in privileges and in waste. Obviously, many other factors had weight, but, in short, the case of southern Italy is relevant because it shows that the difference between the various areas of Europe is not given by the difference between Catholics and Protestants, so much so that Italy is entirely Catholic, but economically and civilly it is still today divided into two distinct areas. The north of Italy is fully in Europe, while the south of Italy is fully in the Mediterranean. On one side there are the 
richest areas of Europe and with the lowest levels of crime; on the other side there are the poorest areas and with the most worrying problems of organized crime.

What happens in the south of Italy takes place throughout the south of Europe, in different ways. Since 1453, with the fall of Constantinople, the confrontation with the Ottoman empire has been felt as an assault, which saves the north and strenuously commits the south of Europe: in the lands of war devastation, fear, flight, and bandits conquer.

The threat of pirates ends only with the Second Barbary War (1815, conducted by the Americans, who did not want to pay the tax to the sea cutter) and the French colonization of Algeria in 1830. On the border between Southern Europe and the Mediterranean, however, the divisions were consolidated, as two sides of the same medal of backwardness. In the southern part of the Mediterranean were the Islamic countries and in the northern part of the Mediterranean feudalism and illiteracy: two different ways of not being Europe anyway. After the Roman thalossocracy, the Mediterranean has been marred, in turn, by the Islamic wars of conquest, by the Christian crusades, by Ottoman expansionism: a permanent conflict that has lasted for centuries, has consumed resources, has hindered trade, economy and modernization.

Often the challenge of the pirates was cited as a difference that allowed the Dutch and then the British to develop a specific sea power, transmigrated from the Mediterranean to the Atlantic. There are many reasons for this epochal change, but this is not the least: Braudel indicates the kidnapping of people for ransom as "the oldest industry" in the Mediterranean, and for various reasons, including this one, he writes that "Europe has built itself from the Mediterranean and thanks to the Mediterranean, but at the same time against the Mediterranean" (Braudel, 1986, p. 23).

For a series of connected factors, a sad destiny united the whole Mediterranean, from Gibraltar to the Golden Horn, including the southern Italians and the southern Spaniards, the Greeks and the Slavs. In many parts of the Mediterranean, the clear perception of a civil inferiority was explicit. When, in 1905, Ortega left Spain for Germany, he said that he was "fleeing the vulgarity of my country to stuff myself with whatever I can get out of it" (Ortega, 2004-2010, IX, p. 24). Within the Generation of 1898, he posed the problem of the rebirth of Spain in apodictic terms: "what is to be done: Hispanization or Europeanization?". He spoke vehemently in favor of regenerating Spain within European borders. For that reason he came into conflict with Miguel de Unamuno (who was proud of the universal value of Spanish and Portuguese cultures) and accused him of preferring to "Africanize" Europe than to "Europeanize" Spain (Ortega, 2004-2010, I, p. 64). To his first son, born in Marburg on 1911, he gave the name Miguel Germán. In 1923 he became the founder of the Revista de Occidente, a veritable "Review of the West". 
Both Unamuno and Ortega appealed to the small intellectual party Agupación al Servicio de la República, dedicated to unite all regions and classes under the same banner, against the "dead ends" of Communism and Fascism. They dreamed of a Republic, but it was the state that was not there and that they intensely wanted, even if in different ways.

This Europe of borders and peripheries can be seen both in a demonic and exorcist manner, or in an exotic and adventurous way, however it is told as a lump of delay and backwardness. Matvejevic writes:

The shores of the Mediterranean have faced modernity with delay, they did not find an answer to his calls. They have not lived the necessary secularity: the Enlightenment was not inclined to them, because it despised superstition, intolerance and obscurantism that continued to dominate over them. The industrial momentum left behind the Mediterranean cities. (1987, p. 117)

The old presumptions on the past and on the peripheries must finally be placed in their context. Today we live in a world that is no longer a slave to history and geography, with its frontiers and its borders. The center of the West has its problems (as shown in Washington by the election of Donald Trump) and the peripheries offer bright lessons, as evidenced by the case of Portugal, which gives lessons to all, with its drug policy and its economic recovery (Barreto, 2017).

\section{A democratic and cosmopolitan Europe}

Reflecting on the twenty years between 1968 and 1989, Dahrendorf underlined the great possibility of building a "democratic, united Europe". He wrote that the old continent was "as yet less real and relevant, and certainly less generous. Still, the fortunate Europe to which we belong exists and has a certain magnetic effect even if it does not discharge its evident responsibility very impressively" (1997, p. 59).

Many of the greatest sociologists, from Beck and Grande (2005) to Habermas (2011), have motivated the vision of a democratic and united Europe. A large part of the battle will be played along the peripheries, frontiers, borders of Europe, in many ways. Some developments have had far-reaching implications, affecting economies, securities, and cultures. In response to this, northern European countries and southern European countries need to remember old reasons and new provisions for confident cooperation. The meanings of center and periphery change a lot. In a flat world, the center is in some way present almost everywhere and 
peripheries are sometimes inside the center. In our liquid modernity, every relationship is put to the test, but cooperation is the only possibility we have.

Many cases of astonishing economic success in Asia teach us that even a centuries-old history can be reversed and redirected. In Singapore, in China, and in many other contexts, history was not a chain at the feet, ineradicable and deterministic. Few nowadays dare to include Ireland in the periphery of Europe. Looking at the Middle-East, Turkey was a country where the second most significant economic growth in the world after China took place for some years. It was not the only case of exceptional development in the area: all the Mediterranean countries can be an opportunity for economic investments, as shown by Turkey (which today constitutes one of the greatest failures of the Western intelligence and diplomacy).

In the literature concerning the West, a confrontation between Manchester and the lower Yangzi valley is relevant (Pomeranz, 2000). The flourishing of the Song dynasty, when the Chinese invented the compass, toilet paper, mechanical printing, and more is prodigious: an excellence that medieval Europe did not have and that it had only afterwards, managing to make up for the delay and establishing a miracle (Jones, 1981) - which until then was not there (Abu-Lughod, 1989). As preeminence did not exist in the sixteenth century, it may not exist in the future (Arrighi, 2007; Bell, 2015).

In our time, any reflection in terms of ethnocentric, national, cultural, racial egoism would be totally inadequate. Everyone is called to play his part, in a world fragmented into extraordinarily different experiences. It will be not easy to find unity, to propose the opportunity of living together, in equal and mutual respect. Peripheries need comprehension and patience, assistance and money, support for modernization and state-building. To some extent, globalization seems ungovernable (Berggruen \& Gardels, 2012), but it remains the only chance we have. The final station of European enlightenment is the cosmopolitan perspective, from Emmanuel Kant to Ulrich Beck. In this sense, Europeanism is the other side of Kant's and Beck's cosmopolitanism; it is a properly understood cosmopolitanism. Nationalisms have brought colonial shames and two world wars; the European and cosmopolitan perspective wants to avoid the repetition of these disasters.

Postwar Europe built the foundations of present global order. From the spatial center of Europe in the in seventieth century, Enlightenment shed light on all frontiers - which are fighting even now the battle of reason. If you turn off the light at Europe's heart, it will be dark for everyone, in Europe. 


\section{References}

Abu-Lughod, J. L. (1989). Before European hegemony. The world system A.D. 1250-1350. New York: Oxford University Press.

Albert, M. (1991). Capitalisme contre capitalisme. Paris: Le Seuil.

Aron, R. (1977). Plaidoyer pour l'Europe décadente. Paris: Laffont.

Arrighi, G. (2007). Adam Smith in Beijing: Lineages of the twenty-first century. London: Verso.

Barker, E. (1944). The development of the public services in Western Europe. New York: Oxford U.P.

Barreto, A. (2017). Tempo de escolha. Lisboa: Relógio D'Água.

Beck, U., \& Grande, E. (2005). Das kosmopolitische Europa: Gesellschaft und politik in der zweiten moderne. Frankfurt am Main: Suhrkamp.

Bell, D. A. (2015). The China model. Princeton: Princeton U P.

Bellah, R. N., \& Tipton, S. M. (2007). The Robert Bellah reader. Durham: Duke U. P.

Bendix, R. (1969). Nation-building and citizenship. New York: Doubleday.

Berggruen, N., \& Gardels N. (2012). Intelligent governance for the 21st century: A middle way between West and East. London: Polity.

Bock, G., Skinner, Q., \& Viroli M. (Eds.) (1991). Machiavelli and republicanism. Cambridge: Cambridge U. P.

Braudel, F. (Dir.) (1977). La Méditerranée. Paris: Arts et métiers.

Braudel, F. (1986). Une leçon d'histoire. Paris: Flammarion.

Caligiuri, M. (1998). Breve storia della Calabria. Roma: Newton \& Compton.

Dahrendorf, R. (1997). After 1989: Morals, revolution and civil society. London: Palgrave.

Duverger, M. (1967). La démocratie sans les peuples. Paris: Fayard.

Eisenstadt, S. N. (2007). 'Multiple modernities' der streit um die gegenwart. Berlin: Kulturverlag Kadmos.

Engels, F. (2009). The conditions of the working class in England. Oxford: Oxford U. P.

Febvre, L. (1935). Le Rhin. Problèmes d'histoire et d'économie. Paris: Colin.

Finantial Times. (2008, September 15th). Pigs in muck. Finantial Times.

Gammone, M. (2014). Center and peripheries in mafia connections. Nauka i društvo, Beograde: 1, Gorapres.

Gammone, M. (2015). The European dream. The frontier in European history. Politeja, Krakow: 37, Jagiellonian University.

Gammone, M. (2017). One village, many tribes, countless wolves. Dangerousness and education in Western thought. In M. Gammone, M. A. Icbay, \& H. Arslan (Eds.), Recent developments in education (pp. 15-20). Bialystok: E-Bwn.

Gammone, M., \& Sidoti F. (2012). Che cosa significa essere europeo? Una ricerca al cuore e ai confini dell'Europa. Milano: FrancoAngeli.

Giannini, M. S. (1986). Il pubblico potere. Stati ed amministrazioni pubbliche. Bologna: il Mulino.

Habermas, J. (2011). Zur verfassung Europas. Ein essay. Suhrkamp: Berlin. 
Jones, E. L. (1981). The European miracle. Cambridge: Cambridge U. P.

Le Goff, J. (2003). L'Europe est-elle née au moyen age?. Paris: Seuil.

Lewis, B. (2001). The Muslim discovery of Europe. New York: Norton.

Lipset, S., \& Rokkan S. (1967). Party systems and voter alignments. New York: Free Press.

Matvejevic, P. (1987). Mediteranski brevijar. Zagreb: Grafic?ki zavod Hrvatske.

Moore, A. (2016). Shakespeare between Machiavelli and Hobbes: Dead Body Politics. Lanham: Lexington.

Murteira, M. (2004). Economia do conhecimento. Lisboa: Quimera.

Ortega \& Gasset, J. (2004-2010). Obras completas. 10 Volúmenes. Madrid: Revista de Occidente.

Pirenne, H. (1937). Mahomet et charlemagne. Paris: Alcan.

Pomeranz, K. (2000). The great divergence. Princeton: Princeton U. P.

Popper, K. (1992). Die offene Gesellschaft und ihre Feinde, Bd. 1, 7 Auflage. Tübingen: Mohr.

Sartori, G. (2011). Cómo hacer ciencia política. Madrid: Taurus.

Shils, E. (1975). Center and periphery: Essays in macrosociology. Chicago: University of Chicago Press.

Torsvik, P. (Ed.) (1981). Mobilization, center-periphery, structures and nation-building. Oslo: Universitetsforlaget.

Touraine, A. (2013). La fin des sociétés. Paris: Seuil.

Venturi, F. (1970). Utopia e riforma nell'Illuminismo. Torino: Einaudi.

Weber, M. (1923). Wirtschaftsgeschichte. Abriß der universalen sozial und wirtschaftsgeschichte. Berlin: Duncker \& Humblot.

Weber, M. (2002). Schriften 1894-1922. Stuttgart: Alfred Kröner Verlag.

Weisser, M. R. (1979). Crime and punishment in early modern Europe. London: Harvester Wheatsheaf.

Mariateresa Gammone. Dipartimento MESVA, Università dell' Aquila, Piazzale S. Tommasi n.1,67100 L'Aquila, Italia.Email: mariateresa.gammone@univaq.it

Data de submissão: 12/05/2018 | Data de aceitação: 21/09/2018 